\title{
COMBINATIONS AND SYNONYMIES IN NEW WORLD LIMACODIDAE, MEGALOPYGIDAE, LASIOCAMPIDAE AND ARCTIIDAE (LEPIDOPTERA)
}

\author{
Marc E. Epstein ${ }^{1}$ \\ Vitor O. Becker ${ }^{2}$
}

\begin{abstract}
Six generic and 65 specific names are synonymized, 26 species are transferred to other genera, 30 removed from synonymy or from subspecific status. Blazia Schaus is transferred from Lymantriidae to Limacodidae, Laruma Walker and Renada Walker from Limacodidae to Lasiocampidae and Arctiidae, respectively. Renada is a junior synonym of Paracles Walker. Several previously unrecognized Brazilian taxa described by Walker, for which types are lost, have been identified.

KEY WORDS. Lepidoptera, Limacodidae, Megalopygidae, combinations, synonymies
\end{abstract}

The synonymies and new combinations in this paper are a result of the preparation of a list for Atlas of Neotropical Lepidoptera (BECKER \& EPSTEIN, in press) (BECKER, in press). Most of these were obtained while checking types and during the course of identifying a synoptic collection taken by Becker to the USNM and to the BMNH.

We also tried to clarify the genera and species described by WALKER $(1855,1856)$, which were regarded as unrecognizable by DYAR (1905: 396). Most of these unrecognized specimens belonged to the Fry Collection. According to Hampson, as reported by DYAR (1905: 359) "...the specimens were returned by Walker in such condition that their acceptance was refused and it is not known what became of them". HORN \& KAHLE (1935-1937) give the location of Fry's collection as the BMNH. We were unable to locate them in the collections of the BMNH and the UMO, where most of Walker types are deposited. Therefore, it is very likely that these specimens do not exist anymore.

Most of the missing taxa were described from specimens collected around Rio de Janeiro, Brazil. We carefuly interpreted Walker's descriptions and selected specimens from the same region as well as from many localities in the Atlantic Forest of Brazil. For all of the species, except for Niaca curvimargo and Amydona punctata, we feel that we have good evidence to recognize their identity. The only previously recognized species from DYAR's list (1905:396)

1) Department of Entomology, National Museum of Natural History, Smithsonian Institution, Washington DC 20560, USA.

2) Centro de Pesquisa Agropecuária dos Cerrados, Empresa Brasileira de Pesquisa Agropecuária, Caixa postal 08223, 73301-970 Planaltina, Distrito Federal, Brasil. 
was Limacodes concolor, as the dalcerid genus Acraga Walker (MILLER, in press).

Lectotypes for syntype series of Druce, Dyar, Dognin and Schaus are designated here. DRUCE did not always mention the number of specimens in his descriptions in the "Biologia" (1887) and elsewhere (1895,1906). Specimens that were examined by Druce, matching type localities in the $\mathrm{BMNH}$, are designated as lectotypes, although we are not certain if syntypes exist elsewhere.

Genera, and species under each genus, are treated in alphabetical order by family or subfamily.

The following abbreviations are used in this work:

AMNH - American Museum of Natural History, New York, USA.

BMNH - The Natural History Museum, London, England.

CMNH - Carnegie Museum of Natural History, Pittsburgh, USA.

LACM - Los Angeles County Museum, Los Angeles, California, USA.

MNHU - Museum für Naturkunde der Humboldt-Universität, Berlin, Germany.

UMO - University Museum, Oxford, England. Mexico.

UNAM - Universidad Nacional Autonoma de Mexico, Mexico City,

USNM - National Museum of Natural History, Washington, USA.

ZSBS - Zoologische Sammlung des Bayerischen Staates, Munich, Germany.

\section{NOMENCLATURAL SUMMARY}

\section{LIMACODIDAE}

Acharia Hübner, [1819] fuscoflava (Dognin, 1910), comb.n.

Blazia Schaus, 1927

antiqua (Dyar, 1905), comb.n.

lixivia (Dognin, 1923), syn.n., comb.n.

Claphidia Dyar, 1921

tersuia (Druce, 1906)

microstagma Dyar, 1921, syn.n.

Epiperola Dyar, 1898

grandiosa Dognin, 1911

cuneata (Strand, 1911), syn.n., comb.n.

peluda (Dognin, 1899)

albimarginata (Kaye, 1901), syn.n.

argentilinea Gaede, 1916, syn.n.

Euclea Hübner, [1819]

baranda Schaus, 1900

cassida Dyar, 1927, syn.n. 
buscki Dyar, 1912

immundara Dyar, 1916, syn.n.

jelyce Dyar, 1926, syn.n.

delphinii (Gray, 1832)

varia (Walker, 1855), syn.n., comb.n..

diversa (Druce, 1887)

obliqua Hy. Edwards, 1886

dolliana Dyar, 1905, syn.n.

spadicis (Grossbeck, 1906), syn.n.

flava Barnes \& McDunnough, 1910, syn.n.

retroversa Dyar, 1907, stat.rev.

urba Druce, 1887, stat.rev.

vericrux Dyar, 1909, stat.rev.

zygia Druce, 1887, stat.rev.

costilinea (Dyar, 1914), syn.n.

Euphobetron Dyar, 1905

cypris (Grote, 1894)

aquapennis Dyar, 1905, syn.n.

hydropteris Dyar, 1937, syn.n.

Euprosterna Dyar, 1905

elaea (Druce, 1887), comb.n..

elaeasa Dyar, 1905, syn.n.

avellana (Dognin, 1910), syn.n.

Isochaetes Dyar, 1899

marinna (Dyar, 1905)

ashtabel Dyar, 1927, syn.n.

hahneli (Hering \& Hopp, 1927), syn.n.

Monoleuca Grote \& Robinson, 1868

occidentalis Barnes \& McDunnough, 1912

fieldi Barnes \& Benjamin, 1925, syn.n.

disconcolorata Barnes \& Benjamin, 1925, syn.n.

Natada Walker, 1855

Mareda Walker, 1855, syn.n.

Vipsorola Dyar, 1920, syn.n.

caria (Druce, 1887), comb.rev.

ceres (Druce, 1887), comb.n..

cochlidionis Dyar, 1907, comb.n..

cora (Schaus, 1920), syn.n.

daona (Druce, 1887), stat.rev.

debella Dyar, 1905, stat.rev.

molicula Dognin, 1911, syn.n. 
dognini Dyar, 1905, stat.rev.

lacipea (Druce, 1890), comb.n..

luscens (Walker, 1855)

ferruginea (Walker, 1855), syn.n., comb.n..

nigripuncta (Barnes \& McDunnough, 1910), stat.rev.

sardites (Druce, 1900), stat.rev.

semivitrea (Schaus, 1920), comb.n..

subpectinata Dyar, 1905

nucea (Dognin, 1920), syn.n.

Perola Walker, 1855

casasi (Beutelspacher, 1988), comb.n..

jorgenseni Schaus, 1921

subpunctella Dyar, 1927, syn.n.

petropolis Dyar, 1905

benedocta Dyar, 1926, syn.n.

sibillanta Dyar, 1926, syn.n.

Platyprosterna Dyar, 1905

elaeetta Dyar, 1905

perpectinata (Dyar, 1905), syn.n., comb.n.

pernambuconis (Dyar, 1905), comb.n.

Prolimacodes Schaus, 1896

badia (Hübner, [1822])

apsorrhoa Dyar, 1925, syn.n.

scaphoides Hering \& Hopp, 1927, syn.n.

trigona (Hy. Edwards, 1882)

dividua Dyar, 1907, syn.n.

undifera (Walker, 1855)

Semyra Walker, 1855

Clamara Walker, 1855, syn.n.

Surida Walker, 1855 syn.n.

bella (Herrich-Schäffer, [1854])

mariae Dyar, 1906, syn.n.

veterna Dognin, 1923, syn.n.

coarctata Walker, 1855, stat.rev.

finita Walker, 1855

moeschleri (Schaus, 1892)

incisa (Walker, 1855), comb.n.

cardia Schaus, 1894, syn.n.

paula Dyar, 1905, syn.n.

eucharista Dyar, 1912, syn.n.

phrygia Dyar, 1921, syn.n. 
erna Dyar, 1927, syn.n.

terminata (Walker, 1855), comb.n.

zynie Dyar, 1905, syn.n.

Talima Walker, 1855

Agisa Walker, 1855, syn.n.

assimilis (Dyar, 1911)

fuscipars (Dyar, 1918), syn.n., comb.n..

ingenour Dyar, 1926

postica Walker, 1855

filifera Dyar, 1926, syn.n.

insulla Dyar, 1927, syn.n.

rufoflava (Walker, 1855), comb.n.

sulla (Schaus, 1892), syn.n.

ieco Dyar, 1926, syn.n.

samula (Druce, 1895), com.n.

straminea (Schaus, 1892)

sissypha Dyar, 1927, syn.n.

Tanadema Dyar, 1905

mas Dyar, 1905

foemina Dyar, 1905, syn.n.

neutra Dyar, 1908

nora Dyar, 1937, syn.n.

Ulamia Möschler, 1883

dolobrata (Stoll, 1780)

sericea (Schaus, 1892), syn.n.

Vipsania Druce, 1887

melanois (Dyar, 1912)

schultzei Hering \& Hopp, 1927, syn.n.

MEGALOPYGIDAE

MEGALOPYGINAE

Megalopyge Hübner, [1820] basalis (Walker, 1856), comb.n.

apicalis (Herrich-Schäffer, [1856]), syn.n.

basigutta (Walker, 1865), syn.n.

globulus (Dognin, 1894), comb.n.

radiata Schaus, 1892

flavivertex Schaus, 1921, syn.n.

Podalia Walker, 1856

amarga (Schaus, 1905), stat.rev.

nigrescens (Schaus, 1905), syn.n.

farmbri Kaye, 1925, syn.n. 
annulipes (Boisduval, 1833), comb.n.

interlineata (Dyar, 1928), syn.n.

contigua (Walker, 1866)

salacia (Druce, 1887), syn.n.

montana (Schaus, 1910), syn.n.

dimidiata (Herrich-Schäffer, [1856])

arpi (Schaus, 1915), syn.n.

habitus (Hy. Edwards, 1887), stat.rev.

intermaculata (Dognin, 1916)

vicina (Hopp, 1926), syn.n.

marmorata (Rothschild, 1910), comb.n.

cirrata Hopp, 1935, syn.n.

Psychagrapha Walker, 1855

floccosa Walker, 1855

TROSIINAE

Aithorape Hopp, 1927

roseicornis (Dognin, 1899)

flammicomis (Schaus, 1905), syn.n.

Coamorpha Dyar, 1913

glutina (Schaus, 1920), stat.rev.

Hysterocladia Felder, 1874

ignicornis (Schaus, 1905)

lena (Schaus. 1912), syn.n.

Trosia Hübner, [1820]

albida (Dognin, 1905), stat.rev.

amala Dyar, 1910, stat.rev.

amarilla Hopp, 1922, stat.rev.

anax Dognin, 1923, stat.rev.

dimas (Cramer, 1775)

donckieri Dognin, 1924, stat.rev.

fallax (Felder, 1874)

flavida Dognin, 1910, stat.rev.

fumosa Hopp, 1934, stat.rev.

incostata Schaus, 1905, stat.rev.

metaleuca (Druce, 1906), stat.rev.

misda Dyar, 1910, stat.rev.

nigra Hopp, 1934, stat.rev.

nigropunctigera Fletcher, 1982

punctigera (Stoll, 1790)

obsolescens Dyar, 1899, stat.rev.

pulla Forbes, 1942 
roseipuncta (Druce, 1906)

rosita Schaus, 1920, stat.rev.

semirufa (Druce, 1906)

tolimata Dognin, 1923, stat.rev.

tricolora (Fabricius, 1787), stat.rev.

zernyi Hopp, 1930

LASIOCAMPIDAE

Euglyphis Hübner, [1820]

punctata (Walker, 1855), comb.n.

falsa (Schaus, 1894), syn.n.

Laruma Walker, 1855

heterogenea Walker, 1855

ARCTIIDAE

Paracles Walker, 1855

Renada Walker, 1855, syn.n.

lateralis (Walker, 1855), comb.n.

INCERTAE SEDIS

Niaca Walker, 1855

curvimargo Walker, 1855

Leucophobetron Dyar, 1897

punctata (Druce, 1901)

\section{LIMACODIDAE}

Acharia fuscoflava (Dognin, 1910), comb.n.

Miresa fuscoflava Dognin, 1910: 40. Holotype male ECUADOR: Loja, 1889 (USNM, 29779) [examined].

Undoubtedly placed in Miresa because of the yellow scales on the dorsum of the thorax and wings. This species has a suite of male genitalic characters that are foreign to Miresa and clearly match Acharia (=Sibine; BECKER \& MILLER, 1988) (EPSTEIN, 1988). These include a ventrally flexed aedeagus, vesica with stout cornuti, prominent manica, and eversible tongue in the transtilla. The female is unknown.

\section{Blazia Schaus, 1927 assig.n.}

Blazia Schaus, 1927:255. Type-species: Orgya lixivia Dognin, 1923:10, by original designation.

This genus, originally included in Lymantriidae, is very closely related to or a synonym of Epiperola or Perola on the basis of the male genitalia and the forked cubital vein in the forewing. 


\section{Blazia antiqua (Dyar), comb.n..}

Platyprosterna antiqua Dyar, 1905:378. Lectotype male, BRAZIL: Paraná, Castro (Jones)(BMNH), here designated [examined].

Orgya lixivia Dognin, 1923:10. Holotype male, BoLIVlA: Rio Songo, 750m (USNM, 29923) [examined]. Syn.n., comb.n.

The size, colour and pattern leave no doubt that these are synonyms. There is no other South American limacodid which can be confused with this species.

\section{Claphidia tersula (Druce)}

Eulimacodes tersula Druce, 1906:90. Lectotype male, PERU: La Oroya, Carabaya, 3000 ft. (BMNH) [examined].

Claphidia microstagma Dyar, 1921: 193. Holotype male, BoLIVIA: Buena Vista (USNM, 24947) [examined]. Syn.n.

A specimen from the type locality of tersula in southeastern Peru closely matches the type of microstagma. Other specimens from nearby central Bolivia and Acre, Brazil (CMNH) also match.

\section{Epiperola grandiosa Dognin}

Epiperola grandiosa Dognin, 1911 [Oct.]:62. Holotype male, FRENCH GUIANA: Nouveaux Chantier, May (Le Moult) (USNM) [examined].

Perola cuneata Strand, 1911 [Dec.]:43. Holotype female, ECUADOR: Macas (Niepelt) (MNHU) [not examined]. Syn.n., comb.n.

In the USNM collection there is a color illustration of the type of cuneata, undoubtedly the female of grandiosa. The forewing pattern is unique among large species in the Perola complex, with the pale fascia running from the base to the tornus, against a dark-brown background. Male and female specimens from Corcovado, Costa Rica, were collected on the same dates by D. Janzen and W. Hallwachs. This species will be kept in Epiperola, since it has only one pair of spurs on the hind tibia, though this group is in need of revision.

\section{Epiperola peluda (Dognin)}

Perola peluda Dognin, 1899:7. Holotype male, COLOMBIA: Micay, VIII.1896 (USNM, 29789) [examined].

Sisyrosea albimarginata Kaye, 1901:158. Holotype male, TRINIDAD: Tabaquite (BMNH) [examined]. Syn.n.

Epiperola argentilinea Gaede, 1916:208. Holotype male, BoLIVIA ['Brazil']: Rio Songo, 1200m, 1896 (Garlepp) [not examined]. Syn.n.

Genitalic preparations of specimens that matched peluda and the darker albimarginata were identical. Both forms were found by Becker to occur at the same place and date (Brazil: Pará, Capitão Poço, 25-31.I.1984). A male from Becker collection has been compared with Dognin and with Kaye's types. 
DYAR (1937) synonymized argentilinea under albimarginata. Epiperola antelia Druce, 1906, may be another synonym of peluda.

\section{Euclea baranda Schaus}

Euclea baranda Schaus, 1900:230. Holotype male, CoLOMBIA: (USNM, 9112) [examined].

Euclea cassida Dyar, 1927:548. Lectotype male, BRAZIL: Amazonas, Caiçara (Dognin) (USNM, 40687), here designated [examined]. Syn.n.

The male genitalia of the holotype of baranda and the paralectotype of cassida are identical. This may be a southern form of Euclea buscki, treated below. The central claw of the uncus is reduced, with lateral iobes expanded, compared to buscki, with central claw and lateral lobes nearly equal and closely spaced.

E. rufa Butler, 1878, examined in the BMNH, may be a senior synonym of baranda or buscki.

\section{Euclea buscki Dyar}

Euclea buscki Dyar, 1912:95. Holotype male, PANAMA: Cabima, May 1911 (Busck) (USNM, 14285) [examined].

Euclea immundara Dyar, 1916:33. Holotype male, Mexıco: Tabasco, Teapa, xi.1913 (Miller) (USNM, 18899) [examined]. Syn.n.

Euclea jelyce Dyar, 1926:81. Lectotype male, CoSTA RICA: Sixaola River (USNM, 28940), here designated [examined]. Syn.n.

Male genitalia of buscki from the type locality match that of the paralectotype of jelyce and specimens that closely match the holotype of immundara Dyar from Veracruz, Mexico and Guatemala.

\section{Euclea delphinii (Gray)}

Limacodes delphinii Gray, 1832:789. Holotype female, USA [no further data] [presumably lost]. Nyssia varia Walker, 1855:1137. Holotype male, locality unknown (Doubleday) [presumably lost]. Syn.n., comb.n.

Walker described varia as "Fore wings with ferruginous flecks, which form zigzag transverse lines, green at the base, and with an irregular green stripe near the interior border, brown varied with green towards the tips." This closely fits the pattern of some forms of delphinii, an extremely variable species. According to WALKER (1855), varia had no locality label, yet he listed varia under "East Indies species". The specimen could well come from North America as did several other mislabeled specimens from Doubleday collection, also described by WALKER. Other like examples of Walker mislabeled North American species were found by FERGUSON (1973). DYAR (1905) listed varia as one of the unrecognized species presumably from the New World fauna. 


\section{Euclea diversa (Druce)}

Semyra diversa Druce, 1887:220. Lectotype female, GuAtemala: Cerro Zunil, 3000 to $4000 \mathrm{ft}$

(Champion) (BMNH), here designated [examined].

It is likely that a specimen placed with the newly designated lectotype in the BMNH collection is a syntype, though it does not have a type label. The labels of this specimen matches the label data (Panama: Bugaba, 800-1500 ft, Champion) and poor condition cited by DRUCE (1887). Hence, we designate this specimen as a paralectotype.

\section{Euclea obliqua Hy. Edwards}

Euclea obliqua Hy. Edwards, 1886:10. Holotype male, USA: "Florida, Indian River" [sic!] (Neumoegen) (USNM) [examined].

Euclea dolliana Dyar, 1905:369. Lectotype female, USA: Arizona, Huachuca Mts, Cochise Co., Palmerlee (Schaeffer) (USNM), here designated [examined]. Syn.n.

Monoleuca spadicis Grossbeck, 1906:289. Holotype male, USA: Arizona, Minnehaha, Yavapai Co., 26.viii (AMNH) [examined]. Syn.n.

Euclea flava Barnes \& McDunnough, 1910:161. Holotype female, USA: Arizona, Pima Co., Babaquivera Mts, (USNM) [examined]. Syn.n.

The holotype of obliqua in the USNM type collection is without label data other than type and Brooklyn Mus. labels. EDWARD'S description of the oblique fascia on the forewings, pointing "towards the apex" matches the type. However, the type specimen is of a species that does not occur in Florida, rather it is synonymous with dolliana, spadicis and flava, all found in southern Arizona. The forewing fascia and forked radial veins, and brushed genitalia all match specimens with these three names.

The types of spadicis and obliqua, both have less contrasting fascia than the lectotype of dolliana. DYAR (1935) placed Monoleuca spadicis in Euclea and Euclea obliqua in Monoleuca. Euclea flava is a yellow form of obliqua. Specimens of the flava form in the USNM collection are primarilly from Gila Co., Arizona, though one additional specimen is from Madeira Canyon, Santa Cruz Co.

\section{Euclea retroversa Dyar, stat.rev.}

Euclea retroversa Dyar, 1907:565. Lectotype male, MEXICO: Cuernavaca, vii.1906 (Schaus) (USNM, 10338), here designated [examined].

E. retroversa was regarded by Dyar (1937) as a subspecies of diversa Druce. Male genitalia of specimens from Veracruz, matching the lectotype of diversa, were compared with the genitalia of the lectotype of retroversa. These preparations belong to clearly distinct species. 


\section{Euclea urba Druce, stat.rev.}

Euclea urba Druce, 1887:216. Holotype male, CosTA RICA: Rio Sucio (Rogers) (BMNH) [examined].

This species has been included in Euprosterna by DYAR $(1905,1937)$ on the basis of its small size and general habitus. However, the two lateral lobes on the uncus of the male holotype and forewing maculation clearly belong in Euclea.

\section{Euclea vericrux Dyar, stat.rev.}

Euclea vericrux Dyar, 1909:156. Holotype female, MEXIco: Veracruz, ex larva (Knab) (USNM, 12628) [examined].

DYAR (1935) synonymized vericrux with diversa. The genitalia of the holotype female of vericrux is clearly distinct from those of specimens that match the female syntype of diversa from Veracruz. We have been unable to locate males from Veracruz that match the holotype. However, vericrux closely resembles members of the retroversa complex, which in turn has similar female genitalia. This is best kept as a species until this complex can be more completely revised.

\section{Euclea zygia Druce, stat.rev.}

Euclea zygia Druce, 1887:216. Lectotype male, PANAMA: Volcan Chiriqui, 2000-3000 ft (Champion) $(\mathrm{BMNH})$, here designated [examined].

Metraga costilinea Dyar, 1914:391. Lectotype male, MExiCO: Tabasco (Müller) (USNM, 16502), here designated [examined]. Syn.n.

Male genitalia of the lectotype of costilinea match those of a specimen from the type locality of zygia. DYAR (1937: 1117) synonymized zygia under plugma Sepp. A male specimen matching SEPP's figure, also from Suriname, has genitalia quite distinct from the genitalia of specimens matching zygia Druce from Panama, Costa Rica and Mexico. Part of the confusion surrounding zygia may be due to the variation in hindwing color, from pale to dark. E. zygia with dark hindwings closely resemble plugma and determinata. Secondly, other species or variants in the plugma complex (E. chiriquensis Schaus and E. colle Dyar) are sympatric with zygia in Panama and Costa Rica, respectively.

The male genitalia of a syntype of determinata $(\mathrm{BMNH})$ is clearly distinct from types of costilinea and zygia. E. costilinea was previously regarded as a form of determinata Druce by DYAR (1937). This led to the misidentification of costilinea as determinata in the U.S. collections. 


\section{Euphobetron cypris (Grote)}

Eudryas cypris Grote, 1894: 8. Holotype male PARAGUAY: (no further data) (BMNH) [examined]. Euphobetron aquapennis Dyar, 1905:387. Lectotype male, PARAGUAY: Sapucay (Forster) (USNM, 9003), here designated [examined]. Syn.n.

Euphobetron hydropteris Dyar, 1937:1131. Lectotype male, CosTA RICA: Sixaola River, iii (Schaus) (USNM, 40772), here designated [examined]. Syn.n.

This is a widely distributed species, which shows variable color patterns, though genitalia are quite homogeneous. The designated paralectotype of aquapennis is a male in the BMNH, Potaro River, Guyana [British Guiana] (Roberts).

\section{Euprosterna elaea (Druce), comb.n.}

Perola elaea Druce, 1887:219, pl. 23, fig. 14. Holotype? male: PANAmA: Volcan de Chiriqui (Ribbe) (MNHU), [not traced].

Euprosterna elaeasa Dyar, 1905:377. Lectotype male, FRENCH GUIANA: St. Jean, Maroni River (USNM, 8987), here designated [examined]. Syn.n.

Natada avellana Dognin, 1910:41. Holotype male, FRENCH GUIANA: La Forestiere, Maroni, iv (Le Moult) (USNM, 29788) [examined]. Syn.n.

The specimen perported to be the type of Perola elaea Druce in the BMNH is not the true type, being both misidentified and not from the type locality. The type locality of elaea is Panamá: Volcan de Chiriqui. The specimen labeled "type" in the BMNH is from Mexico: Jalapa and is a distinct, unrelated species (EPSTEIN, in prep.). DYAR (1905:373, 377) who wrote that he examined DRUCE's type, in all liklihood examined this mislabeled specimen. DYAR (1905) was aware that the "type" was in mixed series and that the other species matched Perola elaea figured in DRUCE, renaming the latter elaeasa Dyar.

The figure of elaea Druce in the 'Biologia' matches the syntypes of elaeasa Dyar. DRUCE's description is vague enough that it could almost match either species, however the "narrow black line crossing from near the apex to the inner margin close to the base" fits the figure better than the Epiclea, which has a less oblique line that is more white than black. Furthermore, it appears that Epiclea does not occur anywhere outside of Mexico, whereas elaea Druce has a much broader distribution from Mexico to Brazil.

The location of the type specimen(s) is given as 'mus. Staudinger', collected by Ribbe (DRUCE, 1887). Through recent correspondence with the MNHU we were unable to locate the type. DYAR (1937) gave the location of the specimen figured in DRUCE [possibly the type] as the Berlin Museum.

It is uncertain that DRUCE had a syntype series, since the number of specimens used in the original description is not montioned. However, a series seems possible, since DRUCE (1887) mentions "one specimen" for two other species on the same page. 


\section{Isochaetes marinna (Dyar)}

Vipsophobetron marinna Dyar, 1905:391. Lectotype female, FRENCH GUIANA: Cayenne (Schaus) (USNM, 9006), here designated [examined].

Isochaetes ashtabel Dyar, 1927:550. Lectotype male, PARAGUAY: Molinas, x.1925 (Schade) (USNM, 40701), here designated [examined]. Syn.n.

Euphobetron hahneli Hering \& Hopp, 1927:182, Fig. 10. Holotype male, BRAzIL: Amazonas, Massauary (Hahnel) (NMHU) [not examined]. Syn.n.

Brushed male genitalia of a specimen from the type locality of marinna (BMNH) matches the genitalia of the type of ashtabel and specimens from Goiás and Planaltina, DF in Central Brazil. A color figure, identified as the type of hahneli in the USNM, matches the type of ashtabel. Genitalia of the type of hahneli (Hopp \& Hering, 1927) matches those from Brazil mentioned above. Specimens range in color from dark (as in the types) to rufous as in I. rufescens (Schaus).

\section{Monoleuca occidentalis Barnes \& McDunnough}

Monoleuca occidentalis Barnes \& McDunnough, 1912:32. Holotype male, USA: San Diego, Cal. (Ricksecker) (USNM) [examined].

Monoleuca fieldi Barnes \& Benjamin, 1925:126. Holotype male, USA: Cal.,Warner's, vii.1917 (G.F.Field) [examined]. Syn.n.

Monoleuca disconcolorata Barnes \& Benjamin, 1925:126. Holotype male, USA: Cal., San Bernardino Mts, Camp Baldy, 8-15.vii (Barnes) (USNM) [examined]. Syn.n.

Male genitalia of specimens matching the three holotypes belong to the same species, with fieldi and disconcolorata as pale morphs of occidentalis.

\section{Natada Walker}

Natada Walker, 1855:1108. Type-species: Natada rufescens Walker, 1855:1109, by subsequent designation by Kirby, 1892:541.

Mareda Walker, 1855:1157. Type-species: Mareda ferruginea Walker, 1855:1157, by monotypy. Syn.n.

Vipsorola Dyar, 1920:197. Type-species: Tanadema semivitrea Schaus, 1920:149, by original designation. Syn.n.

Natada now has four synonyms, including Bombycocera Felder, 1874:pl. 83, fig. 13, [type species: simois (Stoll)].

See Natada semivitrea below.

\section{Natada caria (Druce), comb.rev.}

Perola caria Druce, 1887:219. Holotype male, PANAmA: Volcan de Chiriqui, 2000 to $3000 \mathrm{ft}$ (Champion) (BMNH) [examined].

This species was transferred to Natada from Perola by Dyar (1905) and to Euprosterna by FORBES (1942:384). The male genitalia clearly is related to Natada simois (Stoll, 1780), the complex of Natada fusca (Druce, 1887), and 
most closely to Platyprosterna ceres (Druce), transferred to Natada below. N. caria is a wet forest species in Mexico: Veracruz, Tuxtla Biological Station (Becker), Costa Rica and Panamá. Other closely related species treated below include cochlidionis and lacipea.

\section{Natada ceres (Druce), comb.n.}

Perola ceres Druce, 1887:219. Lectotype female, GuAtemala: Senahu, Rio Maria Linda, $500 \mathrm{ft}$ (Champion) (BMNH), here designated [examined].

This species was transferred to Platyprosterna by DYAR (1905:378). The male genitalia is very close to Natada caria (Druce), only larger. The size and color pattern are clearly disjunct from the previous species, justifying keeping them as separte species. N. ceres occurs in the dry areas on the Pacific slopes of Guerrero and the dry areas of the Yucatán Peninsula, from Campeche, Mexico through Belize, down to Guatemala.

\section{Natada cochlidionis (Dyar), comb.n.}

Euprosterna cochlidionis Dyar, 1907:566. Lectotype male, MEXICO: Guerrero, Iguala, vi.1906 (Schaus) (USNM, 10339), here designated [examined].

Natada cora Schaus, 1920:90. Holotype male, MExico: Sinaloa, Venadio (USNM, 22488) [examined]. Syn.n.

The male genitalia of a light specimen of cora from Sinaloa matches that of the paralectotype of cochlidionis from Cuernavaca (USNM). Related to the caria complex.

\section{Natada daona (Druce), stat.rev.}

Perola daona Druce, 1887:219. Holotype male, CosTA RJCA: [No further data] (Von Patten) (BMNH) [examined].

DYAR (1905:381) regarded this as "probably conspecific with the preceeding [nasoni Grote]", though later (DYAR, 1937) kept them separate. However, recently DAVIS (1983) placed the two species in synonymy. However, comparison of the aedeagus from Costa Rican and U.S. specimens indicate that the two species are in fact distinct, though closely related.

\section{Natada debella Dyar, stat.rev.}

Natada debella Dyar, 1905:379. Holotype male, FrenCH GuIANA: St. Jean, Maroni River (Schaus) (USNM, 8991) [examined].

Natada molicula Dognin, 1911:62. Lectotype male, ARGENTINA: Chaco de Santiago del Estero, Rio Salado, xii (Wagner) (USNM, 29786), here designated [examined]. Syn.n.

Natada debella and dognini were previously synonymized under lucens. Genitalic preparations of the types of debella and dognini are clearly distinct from each other and from two male specimens matching the description of 
lucens from near the type locality in Rio de Janeiro and São Paulo.

The male genitalia of the type of molicula matches those of debella. It appears that molicula is a small, light colored population of debella, sometimes having a trace of the two spots often on the forewing of debella. N. debella ranges from the Guianas to the central plateau of Brazil.

\section{Natada dognini Dyar, stat.rev.}

Natada dognini Dyar, 1905:379. Holotype male, COLOMBIA: Micay, viii.1896 (Dognin) (USNM) [examined].

See debella.

\section{Natada lacipea (Druce), comb.n.}

Perola lacipea Druce, 1890:218. Holotype male, MExICO: Guerrero, Tierra Colorada, $2000 \mathrm{ft}, \mathrm{x.} 1888$ (Smith) (BMNH) [examined].

DYAR $(1905,1937)$ placed lacipea in Euprosterna Dyar. However, the distinctive male genitalia are related to the caria complex.

\section{Natada luscens (Walker)}

Amydona luscens Walker, 1855:1111. Holotype male, BRAZIL: Rio de Janeiro [no further data] (Fry Col.) [presumably lost].

Mareda ferruginea Walker, 1855:1157. Holotype male, BRAZIL: Rio de Janeiro [no further data] (Fry Col.) [presumably lost]. Syn.n., comb.n.

Walker's description of Mareda ferruginea gives enough information to justify this synonymy. The combination of white spots on the front coxae, color pattern and size can be related only to the population of luscens along the Brazilian Atlantic coast.

N. luscens was first placed in Natada by DYAR (1905). DYAR (1937) regarded sardites, debella, and dognini as either forms or subspecies of luscens (see debella).

\section{Natada nigripuncta Barnes \& McDunnough, stat.rev.}

Natada nigripuncta Barnes \& McDunnough, 1910:161-162. Holotype male, USA: Arizona, Prescott (Barnes) [examined].

Natada nigripuncta was previously synonymized with sardites (Dyar, 1937). Although the type of sardites has not been dissected, nigripuncta appears much closer to dognini in the male genitalia and in wing pattern. The type may be either a stray or improperly labelled, since most specimens matching the type are from Tabasco, Mexico south to Panamá. 


\section{Natada sardites (Druce), stat.rev.}

Perola sardites Druce, 1900:512. Holotype male, CoLOMBIA: Minca [no further data] (BMNH) [examined].

This species appears distinct from luscens, which it was previously synonymized with by (DYAR, 1937).

\section{Natada semivitrea (Schaus), comb.n.}

Tanadema semivitrea Schaus, 1920:149. Holotype male, GuATEMALA: Cayuga (Schaus) (USNM, 22494) [examined].

Placed in the monotypic genus Vipsorola by DYAR (1920), semivitrea is one of several species with dark wings and hyaline patches found convergently in New World limacodid genera including Phobetron and Euclea. This species belongs in Natada, sharing a unique combination of male genitalic and other characters. Females remain unknown in collections.

\section{Natada subpectinata Dyar}

Natada subpectinata Dyar, 1905:381. Holotype male, SURINAM: Surinam River, Geldersland (Schaus) (USNM, 8996) [examined].

Tanadema nucea Dognin, 1920:13. Holotype male, FRENCH GUIANA: St. Laurent du Maroni (Le Moult) (USNM, 29803) [examined]. Syn.n.

These were maintained as distinct species after DYAR (1937) transferred nucea to Natada based on minor differences in wing pattern. However these have been found to be highly variable in this genus. DYAR (1937) correctly synonymized urichia Schaus under subpectinata.

\section{Perola casasi (Beutelspacher), comb.n.}

Megalopyge casasi Beutelspacher, 1988:329. Holotype male, MEXıCo: Jalisco, Estación de Biología de Chamela, 24.v.1982 (Pescador) (UNAM) [not examined].

The figures of the male genitalia and wing pattern of casasi [figs 8, 39] clearly belong to a limacodid. The extent and configuration of the valves, uncus, aedeagus and juxtal lobes place this species in the Perola complex.

\section{Perola jorgenseni Schaus}

Perola jorgenseni Schaus, 1921:81. Holotype male, ARGENTINA: Famiosa, vi.1929 (USNM, 23425) [examined].

Perola subpunctella Dyar, 1927:549. Lectotype male, BRAZIL: Paraná, Castro (Jones) (USNM, 40697), here designated [examined]. Syn.n.

Genitalia of both types are identical. 


\section{Perola petropolis Dyar}

Perola petropolis Dyar, 1905:384. Lectotype male, BRAZIL: Rio de Janeiro, Petrópolis (Schaus) (USNM, 9001), here designated [examined].

Perola benedocta Dyar, 1926:91. Holotype male, ARgentinA: Missiones, San Ignacio, Alto Paraná (USNM, 28947) [examined]. Syn.n.

Perola sibillanta Dyar, 1926:92. Holotype male, BRAZIL: São Paulo, Mogy Guaçu (USNM. 28951) [examined]. Syn.n.

This species exhibits variation in color and size, but specimens that match the types in the Becker Collection have identical genitalia.

\section{Platyprosterna elaeetta Dyar}

Platyprosterna elaeetta Dyar, 1905: 378. Lectotype male, BRAZIL: São Paulo (Schaus) (USNM, 8989), here designated [examined].

Natada perpectinata Dyar, 1905: 381. Lectotype male, BRAZIL: Rio de Janeiro (USNM, 8995), here designated [examined]. Syn.n., comb.n.

Specimens in the Becker collection, which match both types, have identical genitalia.

\section{Platyprosterna pernambuconis Dyar comb.n.}

Euprosterna pernambuconis Dyar, 1905:377. Holotype male, BRAZIL: Pernambuco, 29.i.1883 (Koebele) (USNM, 8988) [examined].

The male genitalia, wing pattern, and white scales on the front trochanter reveal a close relationship to the type-species elaeetta discussed above.

\section{Prolimacodes badia (Hübner)}

Noctua badia Hübner, [1822]:pl. 150, figs 696, 697. [Locality not given] [presumably lost].

Prolimacodes apsorrhoa Dyar, 1925:17. Lectotype male, MEXICO: Veracruz, Orizaba, viii.1908 (Müller) (USNM, 27865), here designated [examined]. Syn.n.

Prolimacodes scaphoides Hering \& Hopp, 1927:177. Holotype male, MEXICO: Tabasco (Oberthür) (ZSBS) [not examined]. Syn.n.

Although Hübner did not give the type-locality, his figures match the only Eastern North American species. DYAR (1937) synonymized scapha (Harris), described from Massachussets, with badia and regarded argentimacula Barnes \& McDunnough as a form of it. Genitalia of badia from Massachussets match those of apsorrhoa. Specimens from Guatemala and Veracruz, whose genitalia match the genitalia of the lectotypes of apsorrhoa, also resemble a hand colored photograph of the type od scaphoides (USNM). P. apsorrhoa and scaphoides were previously synonymized under $P$. undifera Walker, discussed below. 


\section{Prolimacodes trigona (Hy. Edwards)}

Limacodes trigona Hy. Edwards, 1882:12. Holotype male, USA: Arizona, Prescott (Doll) (USNM) [examined].

Prolimacodes dividua Dyar, 1907:567. Lectotype male, MExICO: Cuernavaca, viii.1906 (Schaus) (USNM, 10341), here designated [examined]. Syn.n.

Male genitalia of the paralectotype of dividua match those of specimens of trigona from S. Arizona and Chihuahua. The forewings in the Arizona trigona often have less silvery-white scales, especially in the submarginal border of the triangulate patch, compared to an undulating white line in dividua.

\section{Prolimacodes undifera (Walker)}

Limacodes undifera Walker, 1855:1149. Holotype female [listed as male], HONDURAS: [no further data] (Miller) (BMNH) [examined].

This species may either be a synonym of trigona or badia. The triangulate spot on the forewing of the holotype is marked by an undulating white line on the outer margin, similar to dividua. However, the basal portion of the triangle angled towards the costa as in badia.

\section{Semyra Walker}

Semyra Walker, 1855:1130. Type-species: Semyra coarctata Walker, 1855:1131, by subsequent designation by Kirby, 1892:534.

Clamara Walker, 1855:1099. Type-species: Clamara terminata Walker, 1855:1099, by monotypy. Syn.n.

Surida Walker, 1855:1145. Type-species: Surida incisa Walker, 1855:1145, by monotypy. Syn.n.

According to WALKER's descriptions, there is no doubt that the typespecies of the two genera here synonymized belong in Semyra as discussed below. WALKER's generic description of Surida as having antennae with pectinations "broadest in the middle" also gives strong support of this synonymy. Along with Eulimacodes Möschler, there are now three synonyms under Semyra.

Although Clamara Walker has page priority over Semyra Walker, we choose to maintain Semyra in accordance with the first revisor's rule (Article 24a, ICZN). Since Walker's description, Clamara has only appeared in DYAR (1905) (to mention that it was lost) and in FLETCHER \& NYE (1982). Semyra has been used in DYAR $(1905,1937)$, EECKE (1925) and other publications on New World Limacodidae.

\section{Semyra coarctata Walker stat.rev.}

Semyra coarctata Walker, 1855:1131. Holotype male, BRAZIL: Rio de Janeiro (BMNH) [examined]. Semyra finita Walker, 1855:1131. Holotype male, HoNDURAs: [no further data] (Dyson) (BMNH) [examined].

Eulimacodes moeschleri Schaus, 1892:324. Holotype female, MEXICO: Jalapa (Schaus) (USNM, 
9117) [examined].

EECKE (1925) and FLETCHER \& NYE (1982) considered Semyra coarctata to be a synonym of $S$. bella (Herrich-Schäffer). This may have been based, at least in the latter, on fig. 181 in HERRICH-SCHÄFFER (1854), which resembles either species. However, we found the hand colored photograph of bella type in the USNM to best match specimens labelled bella in the USNM collection. These specimens are clearly distinct from coarctata in forewing width (narrower), color pattern and in the male genitalia.

EECKE (1925) synonymized finita Walker and moeschleri Schaus, along with coarctata, under bella. We agreee with DYAR (1937), who considered finita and moeschleri as synonyms, both under coarctata as a "northern form".

\section{Semyra incisa (Walker), comb.n.}

Surida incisa Walker, 1855:1145. Holotype male, BRAZIL: Rio de Janeiro [no further data] (Fry Col.) [presumably lost].

Semyra cardia Schaus, 1894:236. Holotype male, BRAZIL: Paraná, Castro (Schaus) (USNM), 9118), [examined]. Syn.n.

Semyra paula Dyar, 1905:374. Lectotype male, PERU: [no further data] (USNM, 8982), here designated [examined]. Syn.n.

Semyra eucharista Dyar, 1912:95. Holotype female, BRAZIL: [no further data] (USNM, 14082) [examined]. Syn.n.

Semyra phrygia Dyar, 1921:192. Holotype male, BRAZIL: São Paulo, 24.x.1915 (USNM, 24874) [examined]. Syn.n.

Semyra erna Dyar, 1927:549. Lectotype male, PARAGUAY: Villa Rica (Schade) (USNM, 40699), here designated [examined]. Syn.n.

WALKER' (1855) described incisa as having forewings with "blackish undulating stripe in front of the middle partly bordered with white; a silvery subclavate mark in the disk near the base....underside with whitish subapical lunule.". The undulating stripe most clearly matches cardia and the other species here synonymized, whereas the other characters match Semyra. The genitalia of the types of phrygia and erna, as well as those of specimens which match both paula and cardia, all represent one species. The type of eucharista is the female of form phrygia.

Some of the overspliting in this species was probably due to variation in hindwing color, ranging from light yellow in cardia to dark brown in eucharista.

\section{Semyra terminata (Walker), comb.n.}

Clamara terminata Walker, 1855:1099. Holotype female, BRAZIL: Rio de Janeiro [no further data] (Fry Col.) [presumably lost].

Semyra zinie Dyar, 1905:374. Holotype female, PARAGUAY: Sapucay (Forster) (USNM, 9032) [examined]. Syn.n.

"Fawn" colored border along the outer margin as described by WALKER is unique in Semyra. Genitalia from a male specimen matching the type of zinie from Brazil: Goiás (LACM) shows that this is a distinct species. 


\section{Talima Walker}

Talima Walker, 1855:1120. Type-species: Talima postica Walker, 1855:1121, by monotypy. Agisa Walker, 1855:1129. Type-species: Agisa rufoflava Walker, 1855:1129, by monotypy. Syn.n. Agisa is clearly congeneric with Talima.

See discussion under rufoflava.

\section{Talima assimilis (Dyar)}

Sisyrosea assimilis Dyar, 1905: 376. Holotype female, MEXICO: Jalapa (Schaus) (USNM, 8986) [examined].

Euclea fuscipars Dyar, 1918: 366. Holotype female, MEXICO: ["prob. Veracruz"] (Müller) (USNM, 21307) [examined]. Syn.n., comb.n.

Not included in DYAR (1935), fuscipars matches assimilis in wing pattern and size, and is sympatric.

\section{Talima ingenour Dyar}

Talima ingenour Dyar, 1926:84. Holotype male, FRENCH GUIANA: St. Jean, Maroni River (Schaus) (USNM, 28941) [examined]

The three male paratypes from Colombia in the type series of ingenour are misidentified. Genitalic preparation of the two specimens (USNM, coll. Dognin, "Yuntas pres Cali") matches the genitalia of the holotype of Talima aurora Dyar, 1926:84. The third specimen (USNM, coll. Fassl, Colombia), undissected, appears to match the other two. Genitalia of a paratype of ingenour from the type locality are clearly distinct from the type of aurora.

\section{Talima postica Walker}

Talima postica Walker, 1855:1121. Holotype male, VENEZUELA: [no further data] (BMNH) ]examined].

Talima filifera Dyar, 1926:85. Lectotype male, GUYANA: Omai (Schaus) (USNM, 28944), here designated [examined]. Syn.n.

Talima insulla Dyar, 1927:548. Lectotype male, BRAZIL: Amazonas, Rio Solimões, below Codajás, 6.ix.1920, Cornell Univ. Exp., (USNM, 40691), here designated [examined]. Syn.n.

Genitalic preparations of the lectotypes of insulla and filifera match those of a specimen from Trinidad, with the same habitus as the type of postica. These two new synonyms were distinguished from postica by DYAR on the basis of the forewing submarginal line being more distinct in filifera and less so in insulla.

\section{Talima rufoflava (Walker), comb.n.}

Agisa rufoflava Walker, 1855:1129. Lectotype male, BRAZIL: Rio de Janeiro (Fry Col.) [presumably lost].

Nyssia sulla Schaus, 1892:324. Holotype male, BRAZIL: Rio de Janeiro, Petrópolis (USNM, 9115) 
[examined]. Syn.n.

Talima ieco Dyar, 1926:85. Lectotype male, BRAZIL: Paraná, Castro (Schaus) (USNM, 28943, here designated [examined]. Syn.n.

Walker described rufoflava as having red forewings, yellow hindwings with a brown spot on the inner margin, and "9 lines.". This combination of size and color only compare with sulla and ieco of limacodid species found in the Atlantic forests of Brazil. Genitalia of the types of sulla and ieco are conspecific.

\section{Talima samula (Druce), comb.n.}

Grotella samula Druce, 1895:39. Holotype female, MEXICO: [no further data] (BMNH) [examined].

This species is first recognized here as a limacodid, transferred from the Noctuidae. It is placed in Talima, related to the straminea and assimilis complexes (EPSTEIN, in prep.).

\section{Talima straminea (Schaus)}

Semyra straminea Schaus, 1892:324. Holotype female, MEXICO: Veracruz, Rinconada (Schaus) (USNM, 9116) [examined].

Talima sissypha Dyar, 1927:548. Holotype male, GuATEMALA: San Sebastian, Retalhuleu (Thiele) (USNM, 40688) [examined]. Syn.n.

Male genitalic preparations of male straminea from Mexico, near the type locality of Veracruz and San Luis Potosi, and El Salvador, match the brushed valvae of the holotype of sissypha. The unsplit valva in straminea is clearly distinct from the distally divided valva in Talima aurora Dyar and $T$. ingenour Dyar. Dense pads of sensory setae surrounding the ostium bursae of the female genitalia in straminea clearly distinguishes it from aurora (ingenour remains unstudied in this respect).

\section{Tanadema mas Dyar}

Tanadema mas Dyar, 1905:392. Lectotype male, FrEnCH GulAnA: St. Jean, Maroni River (USNM, 9008), here designated [examined]

Tanadema foemina Dyar, 1905:392. Lectotype male, FrenCH GuIANA: St. Jean, Maroni River (USNM, 9009), here designated [examined]. Syn.n.

Genitalia of both lectotypes are identical.

\section{Tanadema neutra Dyar}

Tanadema neutra Dyar, 1908:51. Lectotype male, COSTA RICA: Tuis (Schaus) (USNM, 11542), here designated [examined].

Tanadema nora Dyar, 1937:1133. Lectotype male, COLOMBIA: Juntas Rio Tamana [and] Rio San Juan, 405 ft, ii.1909 (Dognin) (USNM, 40770) here designated [examined]. Syn.n.

Genitalia of the lectotype of nora and the paralectotype of neutra from

Costa Rica (Sixaola River) are identical. 


\section{Ulamia dolobrata (Stoll)}

Phalaena dolobrata Stoll, 1780:34. Type(s), SURINAM: [no further data] [presumably lost].

Amydona sericea Schaus, 1892:324. Holotype male, PERU: [no further data] (Schaus) (USNM, 9130) [examined]. Syn.n.

The type of sericea is only a specimen with darker forewings than normal.

\section{Vipsania melanois (Dyar)}

Pseudovipsania melanois Dyar, 1912:98. Holotype male, CosTA RICA: Tuis, viii.1909 (Schaus) (USNM, 14092) [examined].

Vipsania schultzei Hering \& Hopp, 1927: 185. Holotype male, COLOMBIA: Rio Magadalena, 20.xii. 1920 (Schultze) (Col. Hopp?) [not examined]. Syn.n.

Genitalic preparations of male specimens from Costa Rica (USNM) and western Ecuador (BMNH), south of the type locality of schultzei, are of the same species. A color figure in the USNM of the type of schultzei closely matches the type of melanois, with characteristic red-tipped abdomen. V. unicolor Dyar may be the female of schultzei $[=$ melanois $]$ (Dyar, 1937).

\section{MEGALOPYGIDAE \\ Megalopyginae}

\section{Megalopyge basalis (Walker), comb.n.}

Agisa? basalis Walker, 1856 [10 May]:1757. Holotype male, BRAZIL: Rio de Janeiro (Stephens Col.) [presumably lost].

Ochrosoma apicalis Herrich-Schäffer, [1856]:pl. [91], figs 517, 518. Lectotype male, [fig. 517], [no further data], here designated [not examined]. Syn.n.

Zebonda basigutta Walker, 1865:498. Holotype male, BRAZIL: Rio de Janeiro (BMNH) [examined]. Syn.n.

This is the only species in the Atlantic forests of Brazil that has a forewing with both a white dot at base on the male, and yellow along the apical third of the costa, as described by WALKER for both basalis and basigutta.

\section{Megalopyge globulus (Dognin), comb.n.}

Hydrias globulus Dognin, 1894:94. Holotype male, ECUADOR: Loja, 1890 (Gaujon) (USNM. 29856) [examined].

This species was described in the Lasiocampidae and apparently has not been referred to in any of the major works on the family since then. HEINRICH was aware of its proper family placement, placing it with the Megalopygidae in the USNM collection. 


\section{Megalopyge radiata Schaus}

Megalopyge radiata Schaus, 1892:322. Holotype female, BRAZIL: Rio de Janeiro, Petrópolis (USNM, 12536) [examined].

Megalopyge flavivertex Schaus, 1921:178. Holotype male, BRAZIL: São Paulo, Mato do Governo, i.1921 (Pohl) (USNM, 24928) [examined]. Syn.n.

M. flavivertex was regarded by HOPP (1935) as a form of radiata, the former with yellow on the vertex where the other is white. The type of flavivertex, the only labelled USNM specimen, occurs between the two localities for $M$. radiata, Nova Teutonia and Petrópolis.

\section{Podalia amarga (Schaus), stat.rev.}

Cyclara amarga Schaus, 1905:337. Holotype male, FRENCH GuIANA: St. Jean, Maroni River (Schaus) (USNM, 8926) [examined].

Gois nigrescens Schaus, 1905:338. Holotype male, GUYANA: Omai (USNM, 8927) [examined]. Syn.n.

Megalopyge farmbri Kaye, 1925:423. Holotype female, TRINIDAD: San Fernando, 23.xi.1917 (Farmborough) (BMNH) [examined]. Syn.n.

$P$. amarga, nigrescens, and farmbri were synonymized under dimidiata Herrich-Schäffer by HOPP (1935). Although similar in appearance (see differences under dimidiata below), these species are presumably not sympatric. Specimens of amarga in the USNM and Becker collections range from Costa Rica South to the Atlantic tropical coast of Bahia. Specimens of dimidiata are from Rio de Janeiro South to Parana. P. amarga is chosen as the senior synonym since it has page priority and its holotype is in better condition.

\section{Podalia annulipes (Boisduval), comb.n.}

Bombyx annulipes Boisduval, 1833:87. Holotype male, BOURBON ISLAND [Indian Ocean] (Buquet) (BMNH) [examined].

Malmis interlineata Dyar, 1928:10. Holotype male, BRAZIL: Minas Gerais, Lassance, 15.xi.1919 (Harris) (Cornell Univ., 895) [not examined]. Syn.n.

It is certain that the type of annulipes is mislabelled. This species is from Brazil [series in Becker collection from Distrito Federal: Planaltina and Minas Gerais]. $M$. interlineata has been synonymized with lanocrispa Jones (HOPP, 1935), but both are distinct species.

\section{Podalia contigua (Walker)}

Alpis contigua Walker, 1866:1935. Holotype male, ColomBIA: Bogota (BMNH) [examined].

Alpis salacia Druce, 1887:210. Holotype male, CosTA RICA: Irazu, 6000 to $7000 \mathrm{ft}$ (Rogers) (BMNH) examined]. Syn.n.

Megalopyge montana Schaus, 1910:416. Holotype male, CoSTA RICA: Juan Viãas (Schaus) (USNM) [examined]. Syn.n.

DRUCE (1887) incorrectly identified a specimen of habitus from Gua- 
temala as contigua and later (1897) synonymized the two under contigua. We have examined both types and found them to be distinct species. One specimen from Costa Rica (Volcán Turrialba, 1800m, Col. Becker) was compared with and matched the types of contigua, salacia, and montana. The type of contigua is in a very poor condition, but is still recognizable.

\section{Podalia dimidiata (Herrich-Schäffer)}

Limacodes dimidiatus Herrich-Schäffer, [1856]:pl. [90], fig. 513. Holotype female, BRAZIL: [no further data] [Rio de Janeiro] (MNHU) [not examined].

Repnoa arpi Schaus, 1915:9. Holotype male, BRAZIL: Nova Friburgo (USNM, 18515) [examined]. Syn.n.

The Herrich-Schäffer figure of dimidiata has a contrasting tan border that is wider than those found in the types of amarga and nigrescens (see above). Female specimens from the Atlantic forests of Brazil in the Becker and USNM collections closely match the Herrich-Schaeffer figure and are most likely conspecific with males from the region that match the type of arpi..We suspect that the type locality of dimidiata is Rio de Janeiro because most of HerrichSchäffer's species described from Brazil in the same work belong to this fauna. Likewise, only places in this vicinity were collected in the region at this time.

\section{Podalia habitus (Hy. Edwards), stat.rev.}

Bombyx habitus Hy. Edwards, 1887:91. Holotype male, MEXIcO: Veracruz (Schaus) (AMNH) [examined].

As explained under contigua, this is a different species, not a synonym of the latter as regarded by DRUCE (1897) and HOPP (1935). Hopp's figure of montana (pl. 163, row e) is a good representation of habitus.

\section{Podalia intermaculata (Dognin)}

Bedalia intermaculata Dognin, 1916:22. Lectotype male, Madre de Dios, 500-1200m (Fassl) (USNM, 29833), here designated [examined].

Bedalia vicina Hopp, 1926:197. Holotype male, COLOMBIA: Villa Vicencio (Fassl) (MNHU) [not examined]. Syn.n.

The types of intermaculata in the USNM collection closely match the figure of vicina Hopp from SEITZ. Genitalia slides by Heinrich of the paralectotype of intermaculata from Peru and vicina from Rio de Janeiro appear to be the same and match the illustration of the latter in HOPP (1926). It is unclear whether this figure belongs to the holotype of vicina or another specimen. Hopp mentions a specimen of vicina from Rio de Janeiro. The synonymy makes geographical sense, since type localities are on the east side of the Andes. 


\section{Podalia marmorata (Rothschild), comb.n.}

Antarctia marmorata Rothschild, 1910:178. Holotype male, PERU: Carabaya, Oconeque (Ockenden) (BMNH) [examined].

Podalia cirrata Hopp, 1935. Holotype male, PERU: Carabaya, San Domingo, (Ockenden) (BMNH) [examined]. Syn.n.

Both types come from nearly the same type locality. P. marmorata was described in the Arctiidae.

\section{Psychagrapha Walker}

Psychagrapha Walker, 1855:957. Type-species: Psychagrapha floccosa Walker, 1855:957, by monotypy.

This genus was described in the Psychidae and transferred to Megalopygidae by FLETCHER \& NYE (1928:138).

The female holotype of floccosa is an unmarked, grey moth, presumably belonging to the dimidiata species group, currently in Podalia. It is not synonymized under Podalia because this genus as well as Megalopyge need revision.

\section{Trosiinae Aithorape roseicornis (Dognin)}

Carama roseicornis Dognin, 1899:134. Holotype male, CoLOMBIA: Popayan, 1897 (USNM, 29847) [examined].

Carama flammicornis Schaus, 1905:334. Holotype male, SuRINAM: Geldersland, Surinam River (Schaus) (USNM, 8913) [examined]. Syn.n.

A male from Colombia, the type locality of roseicornis was dissected and its genitalia is identical to those of the type of flammicornis. The synonymy of $A$. bella Druce with roseicomis (Hopp, 1934:1075) appears correct.

\section{Coamorpha glutina (Schaus), stat.rev.}

Vescoa glutina Schaus, 1920:146. Holotype male, GUATEMALA: Cayuga (Schaus) (USNM, 22482) [examined].

This species has been synonymized under C. innoxia (Schaus), however the genitalia are distinct.

\section{Hysterocladia ignicornis (Schaus)}

Trosia ignicornis Schaus, 1905:335. Holotype male, FrenCH GulAnA: St. Jean, Maroni River (Schaus) (USNM, 8916) [examined].

Trosia lena Schaus, 1912:56. Holotype male, CosTA RICA: Juan Viãas, Cachi (Schaus) (USNM) [examined]. Syn.n.

The genitalia of both types are identical. Figure 47 in HOPP (1927) 
matches the genitalia of both types, whereas fig. 46 does not represent ignicornis, rather a misidentified specimen, presumably a form, possibly of werneri Hopp.

\section{Trosia Hübner}

Trosia Hübner, [1820]:196. Type-species: Bombyx tricolora Fabricius, 1787:114, by subsequent designation by DYAR, 1910:169.

There are more than 20 names in this genus, most of them have been regarded by HOPP (1935:1081-1082) as forms, aberrations, or subspecies of dimas (Cramer) and punctigera (Stoll). Most of these forms are widely spread and many are sympatric. Therefore, they cannot be considered subspecies.

They are either discrete forms of the same species, whose genetics and biology would be interesting to elucidate, or they are different species. Their genitalia are almost alike throughout the group, however, on external characters they are quite easy to separate. Taking this into account, it has been decided here to consider all these names as valid specific names. Certainly some of them are synonyms, but this can be sorted out only after a good revision and a careful study of their types. In the Nomenclature Synopsis there is a list of the names currently included in this genus.

\section{LASIOCAMPIDAE Euglyphis punctata (Walker), comb.n.}

Amydona punctata Walker, 1855:1111. Holotype male,BRAZIL:Riode Janeiro [no further data] (Fry Col.) [presumably lost].

Ocha falsa Schaus, 1894:238. Lectotype male, BRAZIL: Paraná, Castro (USNM), here designated [examined]. Syn.n.

The large spot on the cell, row of submarginal spots and the pale ferrugineous color, and narrow zigzag bands on each side of the medial band, as described by WALKER, fits no known Limacodidae from this region, and leaves little doubt that WALKER's type belong to this species of Lasiocampidae. collections.

There are long series of specimens in both the USNM and Becker

\section{Laruma heterogenea Walker}

Laruma heterogenea Walker, 1855:1115. Holotype male, VENEZUELA: [no further data] (UMO) [not examined].

Schaus (1896:634) synonymized Laruma with Hydrias Herrich-Schäffer, currently a synonym of Euglyphis Hübner (Lasiocampidae). This synonymy has been overlooked by all subsequent workers including Fletcher \& Nye (1982:87), who retained it in the Limacodidae. In the USNM collection there is a color figure of the type ordered by SCHAUS, and a series of reared specimens from Venezuela (Distrito Federal, Bajo Seco) which closely match the type figure. 
The species without doubt is a true Lasiocampidae, however, on external characters it does not appear to be congeneric with claudia (Stoll), the type species of Euglyphis. Therefore, we maintain Laruma as valid genus in the Lasiocampidae.

\section{ARCTIIDAE \\ Paracles Walker}

Paracles Walker, 1855:717. Type-species: Paracles contraria Walker, 1855:717, by monotypy. Renada Walker, 1855:771. Type-species: Renada lateralis Walker, 1855, by monotypy. Syn.n.

The genus Renada was originally described in the Arctiidae; it was placed in the Limacodidae by KIRBY (1892). DYAR (1905) listed lateralis as an unrecognized species and it has been regarded as such since then. We believe that WALKER (1855) was correct in the first place. His description of Renada matches that of Paracles. With this, Paracles currently has eight junior synonyms (WATSON \& GOODGER, 1986).

\section{Paracles lateralis (Walker), comb.n.}

Renada lateralis Walker, 1855:771. Holotype female, BRAZIL: Rio de Janeiro [no further data] (Fry Col.) [presumably lost].

According to the description, color, markings and size, it is very likely that this is the female of $P$. fusca Walker, a species widely distributed in southern Brazil and Argentina.

P. fusca have the only females in the genus bearing two marks in the cell, as described by Walker for lateralis.

\section{Incertae Sedis}

\section{Niaca curvimargo Walker}

Niaca curvimargo Walker, 1855:1157. Holotype male, BRAZIL: Rio de Janeiro [no further data] (Fry Col.) [presumably lost].

This could be either a small Euglyphis or a Nolidae.

\section{Leucophobetron punctata (Druce)}

Euclea? punctata Druce, 1901:435. Holotype male, CoLomBlA: Honda (Mus. Druce) |location unknown].

DYAR (1905) placed this species in Leucophobetron without having seen the type, which Druce himself was unable to find during a visit (DYAR, 1905). This species is probably not a limacodid (DYAR, 1905, EPSTEIN \& MILLER, in press). 
ACKNOWLEDGEMENTS. Gratefull acknowledgements are made to the Keeper of Entomology, BMNH, and many of his staff, particularly Drs K. Sattler, A. Watson and I.W.B. Nye, for facilities and advice during our visits to that department. We are also very gratefull to the Chairman of Entomology, USNM, and to Dr. D.R. Davis for facilities and advice during our stay as postdoctoral fellows at the Department of Entomology. Dr. H.J. Hannemann, MNHU, has been always kind to answer our inquires. Drs R. W. Poole, C. Sabrowsky and G.C. Steyskal were consulted about nomenclatural issues, though we accept responsability for all decisions on these matters. Dr. S.E. Miller, Bishop Museum, Hawaii, reviewed the manuscript. Research for this work was partly conducted while both authors had Smithsonian Institution fellowships.

\section{BIBLIOGRAPHIC REFERENCES}

BARNES, W. \& J. McDUNNOUGH. 1910. New species and varieties of North American Lepidoptera. J.N.Y. ent. Soc. 18: 149-162.

.1912. Fifty new species; Notes on the genus Alpheias. Contr. Nat. Hist. Lepid. N. Amer. 1: 1-44.

BARNES, W. \& F. H. BENJAMIN. 1925. Two new Californian limacodid moths. Pan-Pacif. Ent. 1: 126.

BECKER, V.O. (in press). Megalopygidae. In: J.B. HEPPNER (ed.). Atlas of Neotropical Lepidoptera. Checklist: Part II.

BECKER, V.O. \& M.E. EPSTEIN. (in press). Limacodidae. In: J.B. HEPPNER (ed.). Atlas of Neotropical Lepidoptera. Checklist: Part II.

BECKER, V.O. \& S.E. MILLER. 1988. The identity of Sphinx brunnus Cramer and the taxonomic position of Acharia Hübner (Lepidoptera: Limacodidae). J. Res. Lepid. 26: 219-224.

BEUTELSPACHER, C.R. 1988. Lepidópteros de Chamela, Jalisco, Mexico. V. An. Inst. Biol. Univ. Méx. 58: 327-340.

BOISDUVAL, J.B.A.D. DE. 1833. Faune entomologique de Madagascar, Bourbon et Maurice. Lépidoptéres. Paris, Jules Didot L'aine, 122p.

DAVIS, D.R. 1983. Limacodidae, p. 66-67. In: R.W.HODGES (ed.) et al. Check list of the Lepidoptera of America North of Mexico.

DOGNIN, P. 1894. Lépidoptéres de Loja et Enviroins (Equateur). Descriptions d'espéces nouvelles. III. Paris, F. Leve, p.72-97.

- 1899. Hétérocères nouveaux de l'Amerique du Sud. Annls Soc. ent. Belg. 43: 132-148.

— 1910. Hétérocères nouveaux de l'Amérique du Sud. I. Rennes, Oberthür, p.3-46.

. 1911. Hétérocères nouveaux de l'Amérique du Sud. III. Rennes, Oberthür, p.3-66.

. 1916. Hétérocères nouveaux de l'Amérique du Sud. X. Rennes, Oberthür. p.1-25.

- 1920. Hétérocères nouveaux de l'Amérique du Sud. XVIII. Rennes, Oberthür. p.1-13.

1923. Hétérocères nouveaux de l'Amérique du Sud. XXI. Rennes, 
Oberthür. p.1-38.

DRUCE, H. 1887. Biologia cent.-am. Zoologia. Insecta. LepidopteraHeterocera. 1: 201-256.

1895. Descriptions of some new species of Heterocera from tropical America. Ann. Mag. nat. Hist. 16 (6): 36-39.

1897. Biologia cent. am. Zoologia. Insecta. Lepidoptera-Heterocera. 2: 433-440.

1906. Descriptions of some new species of Heterocera from tropical South America. Ann. Mag. nat. Hist. 18 (6): 77-94.

DYAR, H.G. 1905. A list of American Cochlidian moths, with descriptions of new genera and species. Proc. U. S. natn. Mus. 29: 359-396.

-1908. Notes on some American Cochlidiidae, with descriptions of new species. Proc. ent. Soc. Wash. 10: 48-51.

. 1912. Descriptions of new species and genera of Lepidoptera, chiefly from Mexico. Proc. U. S. natn. Mus. 42: 39-106.

- 1914. Descriptions of new species and genera of Lepidoptera from Mexico. Proc. U.S. natn. Mus. 47: 365-409.

1916. Descriptions of new Lepidoptera from Mexico. Proc. U.S. natn. Mus. 51: 1-37.

1918. Descriptions of new Lepidoptera from Mexico. Proc. U.S. natn. Mus. 54: 335-372.

1920. New Lepidoptera, chiefly from Mexico with synonymic notes. Insecutor Inscit. menstr. 8: 187-203.

. 1921. New American moths. Insecutor Insct. menstr. 9: 192-194.

- 1925. Some new american moths. Insecutor Inscit. menstr. 13: 1-19.

. 1926. Notes on some South American Cochlidiidae (Limacodidae). Insecutor Inscit. menstr. 14: 73-95.

- 1927. New species of American Lepidoptera of the families Limacodidae and Dalceridae. J. Wash. Acad. Sci. 17: 544-551.

- 1928. Descriptions of four South American moths. Proc. ent. Soc. Wash. 30: 9-10.

1935-1937. Limacodidae. In A. Seitz. Die Gross Schmetterlinge der Erde. 6. Stuttgart, Kernen. p.1104-1139.

EDWARDS, H. 1882. New species of Heterocera. Papilio 2: 9-15.

1887. Apparently new species of Mexican Heterocera. Entomologica am. 3: 89-92.

EECKE, R. VAN. 1925. Cochlidionidae (Limacodidae). Lepid. Cat. 32: 1-79.

EPSTEIN, M.E. 1988. An overview of slug caterpillar moths (Lepidoptera:

Limacodidae) with emphasis on genera in the New World Parasa group. PhD thesis. Univ.Minnesota. 149p.

EPSTEIN, M.E. \& S.E. MILLER. 1990. Systematics of the West Indian moth genus Heuretes Grote and Robinson (Lepidoptera: Limacodidae). Proc. ent. Soc. Wash. 92: 705-715. 
FABRICIUS, C. 1787. Mantissa insectorum. Hafniae, Chrst. Gottl. Proft. 382p. FELDER, C. \& A.F. ROGENHOFER. Reise der österreichischen Fregatte Novara um die Erde in den Jahren 1857-1859. Zoologischer Theil. 2. 2. Abtheilung: Lepidoptera. Wien, Carl Gerold's Sohn. 2, 9+10+20p.

FERGUSON, D.C. 1973. The species of the genus Tacparia Walker (Lepidoptera, Geometridae. Proc. ent. Soc. Wash. 75: 467-478.

FLETCHER, D.S. \& I.W. B. NYE. 1982. In: I.W.B. NYE (ed.). The generic names of moths of the World. IV. London, British Museum (Natural History), 192p.

FORBES, W.T.M. 1942. The Lepidoptera of Barro Colorado Island, Panama. II. Bull. Mus. comp. Zool. Harv. 90: 264-406.

GAEDE, M. 1916. Neue Lepidoptera des Berliner Zoologischen Museums. Dt. ent. Z. Iris 30: 202-209.

GRAY, G.R. 1832. In: E. GRIFFITH (ed.). The animal kingdom arranged in conformity with the organization by Baron Cuvier. XV. London, Gilbert \& Rivington, 795p.

GROSSBECK, J.A. 1906. A new limacodid. Ent. News 17: 289-290.

GROTE, A.R. 1894. Note on Copidryas platensis. Canadian ent. 26: 8.

HERING, M. \& W. HOPP. 1927. Neue Limacodiden aus Sudamerika. II. Dt. ent. Z. Iris 41: 173-186.

HERRICH-SCHÄFFER, G.A.W. 1850-[1869]. Sammlung neuer oder wenig bekannter aussereuropäischer Schmetterlinge. I. Regensburg, 84p.

HÜBNER, J. 1816-[1826]. Verzeichniss bekannter Schmettlinge [sic!]. Augsburg, $431+72 p$. p.7-24.

HOPP, W. 1926. Megalopygen-Studien. II. Dt. ent. Z. 1926: 193-198. 1927. Die Megalopygiden-unterfamilie der Trosiinae (Lep., Megalopyg.). Mitt. zool. Mus. Berl. 13: 209-336.

. 1930. Ergebnisse einer zoologischen Sammelreise nach Brasilien, insbesondere in das Amazanasgebeit, aus gebiet von Dr. H. Zerny. VI. Lepidoptera: Megalopygidae. Annln naturh. Mus. Wien 44: 269-277.

-1934-1935. Megalopygidae, p.1071-1101.In: A. SEITZ(ed.). Die Gross - Schmetterlinge der Erde. VI. Stuttgart.

HORN, W \& I. KAHLE. 1935-1937. Über entomologische Sammlungen, Entomologen und Entomo-Museologie. Ent. Beih. Berl.-Dahlem 2-4: 1-536. KAYE, W.J. 1901. A preliminary catalogue of the Lepidoptera Heterocera of Trinidad. II. Trans. ent. Soc. Lond. 1901: 115-158.

- 1925. New species and subspecies of Trinidad Rhopalocera and Heterocera. Trans. ent. Soc. Lond. 1925: 413-428.

KIRBY, W.F. 1892. A synonymic catalogue of Lepidoptera Heterocera-moths.

I. Sphinges and Bombyces. London, Taylor \& Francis, 952p.

MILLER, S.E. (in press). Systematics of the Neotropical moth family Dalceridae (Lepidoptera). Bull. Mus. comp. Zool. Harv. 
ROTHSCHILD, W. 1910. Descriptions of new species of Arctianae in the Tring Museum. Novit. zool. 17: 172-188.

SCHAUS, W. 1892. Descriptions of new species of Lepidoptera Heterocera from Brazil, Mexico and Peru. II. Proc. zool. Soc. Lond. 1892: 318-341.

1894. On new Heterocera from tropical America. Proc. zool. Soc. Lond. 1894: 225-243.

1896. On Walker's American types of Lepidoptera in the Oxford University Museum. Proc. zool. Soc. Lond. 1896: 634-650.

1900. New species of Heterocera from tropical America. J. N. Y. ent. Soc. 8: 225-234.

1905. Descriptions of new South American moths. Proc. U. S. natn. Mus. 29: 179-345.

1910. New species of Heterocera from Costa Rica. II. Ann. Mag. nat. Hist. 6 (8): 402-422.

1912. New species of Heterocera from Costa Rica. XII. Ann. Mag. nat. Hist. 9 (6): 34-57.

1915. New species of Heterocera from tropical America. Trans. Am. ent. Soc. 41: 1-9.

. 1920. New species of Lepidoptera in the United States National Museum. Proc. U. S. natn. Mus. 57: 107-152.

. 1921. New species of Lepidoptera in the United States National Museum. Proc. U. S. natn. Mus. 59: 349-396.

. 1927. Lymantriidae, p.536-563. In: A. SEITZ (ed.). Die GrossSchmetterlinge der Erde. VI. Stuttgart.

STOLL, C. 1780. In: P. CRAMER, p.29-90. De uitlandsche Kapellen. IV. Amsterdam, Baalde.

STRAND, E. 1911. Fünf Neue Exotische Heterocera. Fauna exot. 1: 41-43.

WALKER, F. 1855. List of the specimens of lepidopterous insects in the collection of the British Museum. IV. London, British Museum, p.776-796.

- 1855. List of the specimens of lepidopterous insects in the collection of the British Museum. V. London, British Museum, p.977-1257.

- 1856. List of the specimens of lepidopterous insects in the collection of the British Museum. VII. London, British Museum, p.1509-1808.

- 1865. List of the specimens of lepidopterous insects in the collection of the British Museum. XXXII. London, British Museum, p.323-706.

- 1866. List of the specimens of lepidopterous insects in the collection of the British Museum. XXXV. London, British Museum, p.1535-2040.

WATSON, A. \& D.T. GOODGER. 1986. Catalogue of the Neotropical tiger moths. London, British Museum (Natural History), Miscel. publ., 71p.

Recebido em 15.I.1991; aceito em 25.XI.1993. 